\title{
Some Aspects of Management of the Small-Class Schools
}

\author{
Chaloupkova Lucie \\ Masaryk University, Czech Republic
}

\begin{abstract}
The paper is concerned with the various aspects of management of small-class schools. Small-class schools represent a consequential part of the elementary level of the school system (ISCED 1) in the Czech Republic. Management of a school which often comprises of a head-teacher and one or two teachers is a varied, often adventurous process. The following text concentrates particularly on the activities which comprise the school management and on the priorities within its realization. Consequently, the analysis leads to an introduction of a possible explanation of the present situation is like from the point of view of the head teachers of such schools. Moreover, it is concerned with the cooperation between head teacher and school establishing body, this relationship comprising a very important dimension the factual operation of this type of school. The paper is based upon the findings of a questionnaire survey, which took place in March 2008 as a part of research project Smallclass schools in the Czech Republic: an analysis of present situation and their development potential ${ }^{l}$.
\end{abstract}

\section{Introduction}

There can be no doubts about the importance of a multilaterally well-handled management for successful functioning of an organization. Also considering the fact that so-called successful management is influenced by a range of variables, the issue of small-class school management becomes very absorbing. Their specificity is based on conditions typical for small rural schools, which fell victim to budget cuts in public finance during the 'optimization' of the school net, when their uniqueness and contribution yielded to strictly economic interests. In a rather short period of time the Czech schools were bound to deal with demands of a reform of the educational system. The main changes included an obligation to develop an individual school educational programme ${ }^{2}$ and the

\footnotetext{
${ }^{1}$ The project has been realized by the Department of Educational Sciences, Masaryk University, Brno, Czech Republic for the past three years. Apart from the author, the team of the resolvers includes Phdr. Dana Knotová, Ph. D. a Mgr. Kateřina Trnková, Ph. D.

${ }^{2}$ School educational programmes (SEP) for small-class schools were developed on the basis of the Framework Educational Programme for elementary schools. Available from $<$ http://www.vuppraha.cz/soubory/RVPZV 2007-07.pdf $>$ [online] [cit. 20.6.2009].
}

acquisition of juridical subjectivity. The first required for the teachers to cover and deal with an entirely new educational area. The latter meant a substantial transfer of responsibilities and even more importantly of administration onto the head teachers. The small-class schools which were able to withstand the economical-political and demographic pressures form a significant part - more than $35 \%$ of all elementary schools in the Czech Republic. The contribution of such schools for small rural settlements and their residents is often not fully appreciated which is also true for the human resources necessary for their daily functioning. Beside teachers and operating employees this means particularly the head teachers who are often the ones responsible for the actual existence of the school. To this end the paper concentrates on the actual work content of the head teachers role - the way they carry out their work, they would want to carry it out and/or are forced to carry it out; the people/institutions they cooperate with, as well as how and why they do it; and the way they deal with the inevitable accumulation of roles (head teacher, teacher, economist, administrator, etc....).

\section{Research Rationale}

The paper presents partial data acquired during a questionnaire survey for small-class school head teachers in the Czech Republic ${ }^{3}$, sample size $\mathrm{N}=537$ small-class schools (recoverability 35\%). The questionnaire was mailed to the head teachers and to the representatives of their establishing bodies. The approach can be described as a differential inquiry [8]. There were two different mutations of the questionnaires for the two individual target groups, so that some part of the acquired data could be compared. Nonetheless, this paper is based mostly on the response of the head teachers. The interpretation of selected entries of the questionnaire ${ }^{4}$ helps to uncover what comprises the management of a smallclass school, what do head teachers actually do because they have to and what would they prefer to do and why.

School management differs from a classical organizational management, particularly due to the

\footnotetext{
${ }^{3}$ What is typical for a small-class school is that there are not separate classes for each year and in some classes there are pupils of two or more years together.

${ }^{4}$ The questionnaire was analysed by the software Statistika.
} 
distinct aims of the school organization. These fall mainly in the areas of training and education and include educational outcomes, success in educational career and professional assertion with the emphasis on the abilities for lifelong learning, etc. In comparison with classic organizations, which are mainly profit-oriented and whose management has been carefully analysed and described in many publications, the nominal values of such outcomes, or products, is difficult to allocate. The wide spectrum of school functions ${ }^{5}$ clearly implicates that the leadership of such an organization is very difficult. There are many questions, answering which could help us to realize and understand the activities and processes connected to the management of a small-class school. The basic knowledge follows from: What do (head teachers) include among the activities and processes, which they carry out during their school management ${ }^{6}$ ? According to the response, all of the activities fall into the following categories: planning, organizing, pedagogical process, leadership, administration, communication, economic agenda, operation and school development. The categories of administration, economic agenda and communication (in this order) were included most often, followed the activities connected to the management of pedagogical process. This introduces the head teachers more as clerical workers than managers, and therefore corresponds with the previously advertised weak point of the small schools management, the insufficient human resources support in the areas of administration and economic agenda. Even though these activities are very time consuming the head teacher cannot delegate them due to the lack of staff and the lack of financial resources. In fully organized schools these activities are the responsibility of a deputy head teacher or the head teacher's assistant. We have attempted to uncover this 'imbalance' in the small-class schools management by recognition of priorities. We were interested in the head teachers' preferences in the school management process, what do they consider to be of key importance. From the analysis of the responses to what is necessary to provide for an everyday operation of a school it is clear that the time donation for various activities will differ and will depend not only on their real time requirements but will ruled by priorities. The

\footnotetext{
${ }^{5}$ According to Průcha (1995) a school has the following functions: an overall development of individual, protective environment - a guarantee of a healthy and positive environment, education in cultural and social values, formation of individual, school is a tool of the state and a part of living environment. Other possible classification according to function is: personalization, qualification, socialization and integration.

In the questionnaires we decided to use the international term management rather than the Czech word 'řízení' because the first one is more complex and is used more frequently. Moreover, we wanted to uncover the head teachers' understanding of the concept and the meanings they impart to it in their responses.
}

priorities are on the one hand given (official directives from the Ministry of Education) and on the other hand heavily influenced by personal characteristics and values of the head teachers. The personal conception of the profession and one's own visions mingle with the ability and skill to compress all of this into the given boarders without losing the idea of the direction where 'their' (as they often refer to the school they manage) school is heading. The actual question is? "How would you arrange your activities from the point of view of priorities? When selecting priorities we often need to choose between the way we would like to see them and the way we are forced to see them." The respondents chose 5 of their activities according to importance - the most important priority is number 1 . The Table 1a shows the resulting data.

\begin{tabular}{|l|l|l|l|l|}
\hline$\%$ & planning & organizing & Pedag. process & leadership \\
\hline $\begin{array}{l}\text { Forced } \\
\text { priority }\end{array}$ & 12,3 & 15,1 & 46,4 & 28,8 \\
\hline $\begin{array}{l}\text { Chosen } \\
\text { priority }\end{array}$ & 21,0 & 27,5 & 67,8 & 40,0 \\
\hline
\end{tabular}

Table 1a. Forced and chosen priorities according to head teachers of small-class schools $(\mathrm{N}=537$, in \%)

\begin{tabular}{|l|l|l|l|l|l|}
\hline$\%$ & administration & communication & economics & development & operation \\
\hline $\begin{array}{l}\text { Forced } \\
\text { priority }\end{array}$ & 69,8 & 26,6 & 57,2 & 3,7 & 24,6 \\
\hline $\begin{array}{l}\text { Chosen } \\
\text { priority }\end{array}$ & 40,6 & 37,4 & 44,5 & 10,8 & 20,8 \\
\hline
\end{tabular}

Table 1b. Forced and chosen priorities according to head teachers of small-class schools

$$
(\mathrm{N}=537 \text {, in \%) }
$$

We assume that the resulting data (see Table $1 \mathrm{a}, \mathrm{b}$ ) on the one hand describes the reality of the school management and on the other hand serve as a feedback about what the acquisition of juridical subjectivity and the realization of the school educational programmes have meant for schools. Firstly, the data prove that administration and economical agenda almost eliminate the other parts of management activities due to their time consumption and the fact that the head teacher is the only person responsible for the clerical legal acts. The fact that the head teachers consider the activities connected with pedagogical process management as the most important is positive. Nonetheless, the everyday requirements of the public administration reality force them to suspend these. It seems that the main concept of school takes a back seat, the true management of the pedagogical process falls behind the completion of control and regulatory mechanisms of the state. What also strikes us as unfortunate is the low accent put on strategic planning, evaluation, leadership, development and other processes, although these belong among the basic and indispensable components of successful organizational management. The reality shows that 
the acquisition of juridical subjectivity brought new freedom, unfortunately paid for by growing administration, which is supposedly of monitoring but actually of controlling character, demanding economical agenda and groping in the profusion of legislative measures. The possibility to develop an individual school educational programme seems to accord with the chosen priority of pedagogical processes, however, the demands of this reforming process often exceeded the school potential.

The role of a head teacher of a small-class school encompasses a range of associated roles brought about by the specificities of the context. The head teacher still needs to do a good part of teaching, secure the material supply of the school and the integrated facilities (school canteen, observance of safety and hygienic regulations, order teaching aids), and organize a range of school activities and so on. The state is well described by the respondents' explanation of the discrepancy between the forced and chosen priorities. On the individual level these include overburdening of the head teacher (specified as the absence of a secretary), too many responsibilities, impossibility to delegate jobs in a team, etc. On the system level they are the lack of money for education and the dependence on establishing body. The latter fact enables yet another view of the small-class school management and head teacher's job content. Small-class schools in the Czech Republic are established by municipalities, who provide for the school operating and investment costs from their budgets. For small municipalities this is often a hard nut to crack, especially when the small-class school is based in facilities built in 1970s for the requirements of a nine-year elementary school which is now used not even for half the number of students ${ }^{7}$. Nonetheless, the existence of a school in a municipality has a historically valid place and serves as a positive reference to bring young residents and support the social life of the community. This idea is also supported by the research findings, which show that the municipality often cares about the school far more intensively than as required by the law. The establishing bodies are interested in the ways a school can contribute to the community, particularly in the area of social and sport activities of residents.

Table 2a. Which areas of school life is the establishing body interested in? $(\mathrm{N}=537)$

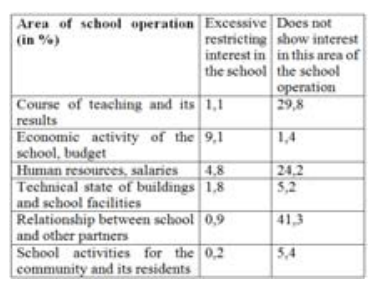

${ }^{7}$ Many rural schools were built after the WWI, which means their maintenance is quite costly.
Table $2 \mathrm{~b}$. Which areas of school life is the establishing body interested in? $(\mathrm{N}=537)$

\begin{tabular}{|l|l|l|}
\hline Area of school operation & $\begin{array}{l}\text { Active } \\
\text { interest in } \\
\text { the school, } \\
\text { its support }\end{array}$ & $\begin{array}{c}\text { Adequate } \\
\text { interest } \\
\text { in the } \\
\text { school }\end{array}$ \\
\hline $\begin{array}{l}\text { Course of teaching and its } \\
\text { results }\end{array}$ & $10.6 \%$ & $55.8 \%$ \\
\hline $\begin{array}{l}\text { Economic activity of the } \\
\text { school, } \\
\text { budget }\end{array}$ & $51.7 \%$ & $37.6 \%$ \\
\hline Human resources, salaries & $11.2 \%$ & $57.2 \%$ \\
\hline $\begin{array}{l}\text { Technical state of } \\
\text { buildings } \\
\text { and school facilities }\end{array}$ & $41.2 \%$ & $49.9 \%$ \\
\hline $\begin{array}{l}\text { Relationship between } \\
\text { school } \\
\text { and other partners }\end{array}$ & $10.2 \%$ & $43.7 \%$ \\
\hline $\begin{array}{l}\text { School activities for } \\
\text { the community and its residents }\end{array}$ & $50.3 \%$ & $42.8 \%$ \\
\hline
\end{tabular}

In the functioning of small-class schools we can trace down various spheres of influence, which can occasionally mingle, but in reality each participant 'plows one's own furrow' and the respect for individual spheres has a positive influence on mutual relationships among the participants as described below. According to the head teachers the establishers are most interested in the school economic management, its budget, and this is also the area, in which they actively involved. In municipality budgets the entry 'school/costs' often represents a relatively high number. In case a school suffers from a lack of pupils, the establishing body needs to apply for an exception ${ }^{8}$ and consequently also cover the teacher salaries. The main part of the establisher's responsibility is, however, connected to the school building which is a property of the municipality. And that is also the main area of conflict in the communication between the establishing bodies and the head teachers. The head teachers are therefore the ones who "always ask for something for the school" and the mayors are the

\footnotetext{
$8 \quad$ Thece as a regulation for a minimum numer of pupila in a class according to the type of school. A one-class school needs to have at least 10 pupils and two-class school needs to have on average a minimum of 12 pupils per one class, a three-class school on average a minimum of 14 pupils per one class. Classes at the lower levels of higher organized elementary schools are required to have an average at least 15 students per class (according to a directive no. 48/2005 Sb., § 4). In case the regulation is broken and there are less pupils than required, the establishing body needs to decide whether to close the school down or to grant the school an exception and subsidize teachers' salaries. The wage spending of elementary schools, including small-class schools, are financed from the budget of the Ministry of Education. This institution also provides financially for the further education of pedagogical employees and activities directly connected to development of schools and education. The size of the financial means is determined by a normative per pupil, the construction of which is rather complicated. Operational and investment costs are covered by the school establishing body (in case of small schools, by the municipality).
} 
ones who "always need to remove new and new defects, invest in the school building, the sport facilities, etc.). The buildings of the small-class schools are often not new; in some cases they are historical buildings (which have recently celebrated a centennial anniversary). In other cases the building is a heritage of a fully organized school often from the 1970s (a decade of a 'baby boom', followed by establishing of new kindergartens and elementary schools). In 1990s the schools needed to deal with very low-number cohorts. The number of children in small municipalities grew much lower also thanks to a change in the life style - many children attend schools in catchment towns, where their parents commuted for work. The school buildings of many small-class schools are not fully made the use of, their operation is very costly also due to the need for their renovation (additional insulation, new roofing, new windows, etc.). Last but not least the school equipment is also expensive (interactive boards, teaching needs, adjustable chairs and desks, IT facilities, etc.). In conclusion, the high cost intensity of school buildings usually represents a strong argument is the discussion about the existence/nonexistence of a school in the particular municipality and is always one of the biggest and repeated issue for the head teachers.

Needless to say a school in a municipality represents an important, in fact indispensable, part of its civic amenities, and it is expected to provide certain services. On the one hand an existence of a school is a prestigious matter (it serves as one of the indicators of the municipality development, the way provides for its residents ...) and on the other hand it should saturate the social needs of the community (it often holds public performances such as concerts, children parties, children's performances prepared for Mother's Day and Christmas, theatres, classes for adults, sport event and it also organizes trips to theatres). According to mayors, the main reasons for running a school are tradition, improvement of civic amenities, cultural activity and protecting children from having to commute.

The areas of educational content and development of educational approaches rather surprisingly belong to the sphere where the influence of teachers and the establisher can overlap. The head teachers express an adequate concern from the establisher's side concerning the matters of the mode of teaching and its results and these are directly connected to the municipality prestige, the quality of its service provided for the parents A school which is able to prepare pupils for a transfer to the higher levels of education, often to fully organized urban schools, serves as a good 'business card' and a good advertisement for the municipality. The context of a small municipality is in this case quite specific. All the residents know each other and share information every day in the shop, in the post office, in the local pub.... If anything happens in the school, the local authorities will know it straight away through rumour: "... and what did your kid do?" "How did your John manage?" On the other hand small school teachers often need to face disapproval when introducing new educational approaches. Parents see the traditional methods, which they themselves experienced, as time-tested. Project education, team work, experiential learning, etc. seem suspicious; parents may be worried that their children will not cover all the subjects that they do not sit properly at their desks and making notes. The rural inhabitants' conservative views and their reluctance to understand and except new things may be induced by their lower socio-economic status (including lower education) [9]. All of this can influence the local authorities' adequate concern for education in their local schools. Adequate meaning not disturbing, i.e. when on the one hand the teachers' competences are not disturbed and on the other hand the head teachers do not see this as a lack of interest. This may be the reason why the head teachers evaluated their cooperation and communication with the establishing body as very good. Not only the head teachers' opinions but also the point of view of establishing bodies (local authorities) is very important for understanding the small-class school management, although their responsibilities and authority should not collide with each other. According to the questionnaire responses, the establishing body participates together with teachers on school management (especially on leading and organization of school events and acquiring of financial means).

It is important to find out about the local authorities' assessment of the pedagogical and operating staff of school. Consequently, we can compare the views of head teachers and establishers, the way they view each other and the way they evaluate their mutual relationship. We have already seen that the head teachers evaluated their cooperation and communication with the establishing bodies as very good and that they are rather satisfied with the work of individual bodies which influence the operation of school. The mayors were asked the following question: "what is your main reason for being satisfied / dissatisfied with the work of pedagogical and operating staff in the small-class school? and marked their answers on a four-point scale: (1) - very important, (4) not important at all. As it emerged, the mayors are very satisfied with the fact that all staff take care of the good reputation of their school (mayors 1, 38) and maintain good relationship with pupils' parents (mayors 1,51). This information complies with the described context of small municipalities, their rural character, with the low number of inhabitants, whose relationship is usually close, communication is informal but regular and it takes place in typical rural setting. Solidarity with local municipality, taking care of its good 
reputation through positively valued activities, when the advertising of a school goes hand in hand with advertising of a municipality, is a fortunate strategy for both, the small-class school and its establishing body. The second field which also demonstrated high satisfaction was thus naturally communication (mayors 1,53) and the fact that teachers carry out their jobs excellently (mayors 1,53 ).

\section{Conclusion}

It seems that mutually responsive communication and cooperation, bringing profit to all parties, is a tried and tested formula for preservation of a wellfunctioning small-class school in a municipality. In many cases it is a yearly fight for survival, which is in the end always decided by yet another party - the parents. The net of settlements in the Czech Republic is rather dense and daily commuting for work is quite common. And that is exactly the variable which enters the decision process of what school is a child going to attend. Whether it will be a school in their place of residence or in the town, where the parents work. Therefore, the ability to advertise itself, the strategy for gaining new students, the satisfaction of existing pupils and their parents and the roles a school holds are all extremely important. The main part of the responsibility for what the school is at the moment and is going to be in the future lies on the head teacher and her/his small team. As we could see, the management of a small-class school is multilayered process which and is definitely not restricted only to the school building and the people and processes inside it, on the contrary. Besides facilitating for the basic needs of the school (its pupils but also the staff), is concerns a strategic management of relationship nets which surround it. The head teacher represents a public institution and is responsible for all the practical matters as clarified by legal regulations as well as for moral ethos connected with education. The character, visions, intentions and personal aims of the head teachers are no less important. All these projects into the state and the quality of the relationships which the school representatives initiate, maintain and strengthen. The outcome is a 'business card' which presents the school to its staff, pupils, parents, citizens and establishing bodies. Nonetheless, the research outcomes show a tendency towards orienting the management on coping with the day-to-day operation of the school in the way delimited by legislative regulations, and therefore the administrative and economic agenda is what the head teachers need to deal with and what 'steals' time for remaining processes, which are traditionally considered to have more value and are indispensable for the preservation of the quality of school (such as educational process, evaluation, planning and school development). Many head teachers feel this discrepancy very intensively and personally still place the emphasis on educational process and on their personal engagement in its development, on improvement of quality and in a development of the school as such.

In conclusion, after years of influx of responsibilities in new areas the small-class schools seem to be entering a calmer phase, when the the basic model of the school operation has been created and stabilized. The leadership can be less intensive and there may be more space for motivating and supporting teachers, for strategic development (which was perhaps being neglected) and for realizing visions. However, this development would require a purposeful support, especially in the field of human resources and in finances from the responsible bodies on the state and regional level.

\section{References}

[1] J.H.Donelly, J.L.Gibson, J.M. Ivancewich, Management, Grada Publishing, Prag, 1997.

[2] Stephen P. Robbins, Mary Coulter, Management, Grada Publishing, Prag, 2004.

[3] P. F. Drucker, Cestou $k$ zitřku. Management pro 21.století, Management Press, Prag, 1993.

[4] G. Southworth, Primary School Leadership in Context: Leading Small, Medium and Large Sized Primary Schools, Routledge\&Falmer, London, 2004.

[5] M.Pol, Škola v proměnách, Masarykova univerzita, Brno, 2007.

[6] J.Průcha, Pedagogický slovnik, Portál, Praha, 2003.

[7] B.Pont, D. Nusche, D. Hopkins, Improving School Leadership Volume 1: Policy and Practice,Volume 2: Case studies on systém leadership. OECD, Paris, 2008.

[8] J.Ferjenčík, Úvod do metodologie psychologického výzkumu. Jak zkoumat lidskou duši, Portál, Praha, 2000.

[9] M. Tuček, Sociálni struktura venkova a mobilita jeho obyvatel. In Český venkov 2003. Situace pred vstupem do EU. PEF ČZU, Praha, 2003. S. 197-208 